\title{
Front Matter: Volume 8937
}

, "Front Matter: Volume 8937," Proc. SPIE 8937, Multimodal Biomedical Imaging IX, 893701 (20 February 2014); doi: 10.1117/12.2053710

SPIE. Event: SPIE BiOS, 2014, San Francisco, California, United States 


\section{Multimodal Biomedical Imaging IX}

Fred S. Azar

Xavier Intes

Editors

1-2 February 2014

San Francisco, California, United States

Sponsored and Published by

SPIE 
The papers included in this volume were part of the technical conference cited on the cover and title page. Papers were selected and subject to review by the editors and conference program committee. Some conference presentations may not be available for publication. The papers published in these proceedings reflect the work and thoughts of the authors and are published herein as submitted. The publisher is not responsible for the validity of the information or for any outcomes resulting from reliance thereon.

Please use the following format to cite material from this book:

Author(s), "Title of Paper," in Multimodal Biomedical Imaging IX, edited by Fred S. Azar, Xavier Intes, Proceedings of SPIE Vol. 8937 (SPIE, Bellingham, WA, 2014) Article CID Number.

ISSN: 1605-7422

ISBN: 9780819498502

Published by

SPIE

P.O. Box 10, Bellingham, Washington 98227-0010 USA

Telephone +1 3606763290 (Pacific Time) · Fax +1 3606471445

SPIE.org

Copyright $@ 2014$, Society of Photo-Optical Instrumentation Engineers.

Copying of material in this book for internal or personal use, or for the internal or personal use of specific clients, beyond the fair use provisions granted by the U.S. Copyright Law is authorized by SPIE subject to payment of copying fees. The Transactional Reporting Service base fee for this volume is $\$ 18.00$ per article (or portion thereof), which should be paid directly to the Copyright Clearance Center (CCC), 222 Rosewood Drive, Danvers, MA 01923. Payment may also be made electronically through $\mathrm{CCC}$ Online at copyright.com. Other copying for republication, resale, advertising or promotion, or any form of systematic or multiple reproduction of any material in this book is prohibited except with permission in writing from the publisher. The CCC fee code is $1605-7422 / 14 / \$ 18.00$.

Printed in the United States of America.

Publication of record for individual papers is online in the SPIE Digital Library.

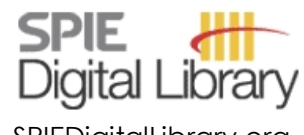

SPIEDigitalLibrary.org

Paper Numbering: Proceedings of SPIE follow an e-First publication model, with papers published first online and then in print and on CD-ROM. Papers are published as they are submitted and meet publication criteria. A unique, consistent, permanent citation identifier (CID) number is assigned to each article at the time of the first publication. Utilization of CIDs allows articles to be fully citable as soon as they are published online, and connects the same identifier to all online, print, and electronic versions of the publication. SPIE uses a six-digit CID article numbering system in which:

- The first four digits correspond to the SPIE volume number.

- The last two digits indicate publication order within the volume using a Base 36 numbering

system employing both numerals and letters. These two-number sets start with 00, 01, 02, 03, 04,

$05,06,07,08,09,0 A, 0 B \ldots$. OZ, followed by 10-1Z, 20-2Z, etc.

The CID Number appears on each page of the manuscript. The complete citation is used on the first page, and an abbreviated version on subsequent pages. Numbers in the index correspond to the last two digits of the six-digit CID Number. 


\section{Contents}

vii Conference Committee
ix Introduction

\section{SESSION 1 IMAGING IN SURGICAL PROCEDURES}

893703 A surgical navigation system for non-contact diffuse optical tomography and intraoperative cone-beam $\mathrm{CT}$ [8937-2]

M. J. Daly, Univ. of Toronto (Canada) and Univ. Health Network (Canada); N. Muhanna, H. Chan, Univ. Health Network (Canada); B. C. Wilson, J. C. Irish, Univ. Health Network (Canada) and Princess Margaret Cancer Ctr. (Canada); D. A. Jaffray, Univ. of Toronto (Canada), Univ. Health Network (Canada) and Princess Margaret Cancer Ctr. (Canada)

893704 Multimodal confocal mosaics enable high sensitivity and specificity in screening of in situ squamous cell carcinoma [8937-3]

M. Grados Luyando, A. Bar, N. Snavely, S. Jacques, Oregon Health and Science Univ. (United States); D. S. Gareau, Oregon Health and Science Univ. (United States) and The Rockefeller Univ. (United States)

893706 A simultaneous multimodal imaging system for tissue functional parameters [8937-5] W. Ren, Z. Zhang, Q. WU, S. Zhang, Univ. of Science and Technology of China (China); R. XU, Univ. of Science and Technology of China (China) and The Ohio State Univ. (United States)

\section{SESSION 2 MICROSCOPY}

893709 In vivo hyperspectral CARS and FWM microscopy of carotenoid accumulation in $\mathrm{H}$. Pluvialis [8937-8]

A. D. Slepkov, Trent Univ. (Canada); A. M. Barlow, National Research Council Canada (Canada) and Univ. of Ottawa (Canada); A. Ridsdale, P. J. McGinn, National Research Council Canada (Canada); A. Stolow, National Research Council Canada (Canada) and Univ. of Ottawa (Canada)

\section{SESSION 3 MULTIMODAL TOMOGRAPHY/SPECTROSCOPY IMAGING}

8937 OD A parallel framework for simultaneous fNIRS/fMRI fusion [8937-12]

Z. Yuan, Univ. of Macau (Macao, China)

$8937 \mathrm{OH} \quad$ Validation of temperature-modulated fluorescence tomography in vivo [8937-16]

T. C. Kwong, F. Nouizi, Y. Lin, R. Rajyaguru, T. Nguyen, L. Alptekin, Univ. of California, Irvine (United States); U. Sampathkumaran, Y. Zhu, S. Ahmed, InnoSense LLC (United States);

G. Gulsen, Univ. of California, Irvine (United States) 
8937 OK One-step microencapulation of nanoparticles and perfluorocarbon in microbubbles for potential application in controlled activation [8937-19]

G. Li, T. Si, X. Luo, Univ. of Science and Technology of China (China); R. Xu, Univ. of Science and Technology of China (China) and The Ohio State Univ. (United States)

8937 OL Single snapshot RGB multispectral imaging at fixed wavelengths: proof of concept [8937-20]

J. Spigulis, L. Elste, Univ. of Latvia (Latvia)

8937 OM Microencapsulation of multiple components by compound-fluidic electro-flow focusing [8937-21]

C. Yin, T. Si, P. Gao, Univ. of Science and Technology of China (China); R. X. Xu, Univ. of Science and Technology of China (China) and The Ohio State Univ. (United States)

8937 ON A fast and effective reconstruction method for fluorescence molecular tomography based on sparsity adaptive subspace pursuit [8937-22]

J. Ye, C. Chi, Institute of Automation (China); Y. An, H. Xu, Beijing Jiaotong Univ. (China);

S. Zhang, Northeastern Univ. (China); X. Yang, J. Tian, Institute of Automation (China)

POSTER SESSION

$893700 \quad$ IRF-calibrated Born normalization scheme for time-domain diffuse fluorescence tomography based on overlap time-gating [8937-23]

F. Gao, Tianjin Univ. (China) and Tianjin Key Lab. of Biomedical Detecting Techniques and Instruments (China); P. Liu, W. Wan, Tianjin Univ. (China); J. Li, H. Zhao, Tianjin Univ. (China) and Tianjin Key Lab. of Biomedical Detecting Techniques and Instruments (China)

8937 OP Dental imaging using laminar optical tomography and micro CT [8937-28]

F. Long, M. S. Ozturk, X. Intes, S. Kotha, Rensselaer Polytechnic Institute (United States)

8937 OR High resolution 3D image reconstruction in laminar optical tomography based on compressive sensing [8937-30]

F. Yang, Shandong Institute of Business and Technology (China) and Rensselaer Polytechnic Institute (United States); M. S. Ozturk, W. Cong, G. Wang, X. Intes, Rensselaer Polytechnic Institute (United States)

8937 OS Mesh optimization for fluorescence molecular tomography [8937-31]

A. Edmans, C. Smith, X. Intes, Rensselaer Polytechnic Institute (United States)

8937 OT Structured light based hyperspectral time-resolved diffuse optical tomography system [8937-32]

Q. Pian, X. Intes, Rensselaer Polytechnic Institute (United States)

8937 OU Unsupervised clustering analyses of features extraction for a caries computer-assisted diagnosis using dental fluorescence images [8937-33]

M. Bessani, M. M. da Costa, Univ. de São Paulo (Brazil); E. C. C. C. Lins, Univ. Federal do ABC (Brazil); C. D. Maciel, Univ. de São Paulo (Brazil) 
$8937 \mathrm{OV}$ Comparison of $\mathrm{I}_{\mathrm{p}}$-regularization-based reconstruction methods for time domain fluorescence molecular tomography on early time gates [8937-34]

L. Zhao, H. Yang, W. Cong, G. Wang, X. Intes, Rensselaer Polytechnic Institute (United States)

8937 OW Diffuse fluorescence tomography based on the radiative transfer equation for small animal imaging [8937-36]

Y. Wang, Tianjin Univ. (China); L. Zhang, H. Zhao, F. Gao, J. Li, Tianjin Univ. (China) and Tianjin Key Lab. of Biomedical Detecting Techniques and Instruments (China)

8937 OX Comparison of NIR FRET pairs for quantitative transferrin-based assay [8937-37]

N. Sinsuebphon, Rensselaer Polytechnic Institute (United States); T. Bevington, Albany Medical College (United States); L. Zhao, Rensselaer Polytechnic Institute (United States); A. Ken, M. Barroso, Albany Medical College (United States); X. Intes, Rensselaer Polytechnic Institute (United States)

$8937 \mathrm{OZ}$ Optimal arrangements of fiber optic probes to enhance the spatial resolution in depth for 3D reflectance diffuse optical tomography with time-resolved measurements performed with fast-gated single-photon avalanche diodes [8937-24]

A. Puszka, CEA-LETI (France); L. Di Sieno, A. Dalla Mora, A. Pifferi, D. Contini, G. Boso, A. Tosi, Politecnico di Milano (Italy); L. Hervé, A. Planat-Chrétien, A. Koenig, J.-M. Dinten, CEA-LETI (France)

893710 Time-resolved measurements in diffuse reflectance: effects of the instrument response function of different detection systems on the depth sensitivity [8937-25]

A. Puszka, A. Planat-Chrétien, M. Berger, L. Hervé, J.-M. Dinten, CEA-LETI (France)

893713 Novel fusion for hybrid optical/microcomputed tomography imaging based on natural light surface reconstruction and iterated closest point [8937-35]

N. Ning, Harbin Univ. of Science and Technology (China); J. Tian, Institute of Automation (China) and Xidian Univ. (China); X. Liu, Harbin Univ. Of Science and Technology (China);

K. Deng, Xidian Univ. (China); P. Wu, Institute of Automation (China); B. Wang, Harbin Univ. of Science and Technology (China); K. Wang, X. Ma, Institute of Automation (China)

893714 Combining 3D optical imaging and dual energy absorptiometry to measure three compositional components [8937-38]

S. Malkov, J. Shepherd, Univ. of California, San Francisco (United States)

893717 Simulation of optical breast density measurements using structured light illumination [8937-42]

J. Kwong, F. Nouizi, Y. Li, J.-H. Chen, M.-Y. Su, G. Gulsen, Univ. of California, Irvine (United States)

Author Index 
Proc. of SPIE Vol. $8937893701-6$

Downloaded From: https://www.spiedigitallibrary.org/conference-proceedings-of-spie on 26 Apr 2023 Terms of Use: https://www.spiedigitallibrary.org/terms-of-use 


\title{
Conference Committee
}

\author{
Symposium Chairs
}

James G. Fujimoto, Massachusetts Institute of Technology

(United States)

R. Rox Anderson, Wellman Center for Photomedicine, Massachusetts General Hospital (United States) and Harvard School of Medicine (United States)

Program Track Chairs

Tuan Vo-Dinh, Fitzpatrick Institute for Photonics, Duke University (United States)

Anita Mahadevan-Jansen, Vanderbilt University (United States)

\section{Conference Chairs}

Fred S. Azar, Philips Medical Systems (United States)

Xavier Intes, Rensselaer Polytechnic Institute (United States)

Conference Program Committee

Caroline Boudoux, Ecole Polytechnique de Montréal (Canada)

Yu Chen, University of Maryland, College Park (United States)

Qianqian Fang, Massachusetts General Hospital (United States)

Sergio Fantini, Tufts University (United States)

Gultekin Gulsen, University of California, Irvine (United States)

Theodore J. Huppert, University of Pittsburgh (United States)

Tim Nielsen, Philips Research (Germany)

Vasilis Ntziachristos, Helmholtz Zentrum München GmbH (Germany)

Brian W. Pogue, Thayer School of Engineering at Dartmouth (United States)

Siavash Yazdanfar, GE Global Research (United States)

Arjun G. Yodh, University of Pennsylvania (United States)

Session Chairs

1 Imaging in Surgical Procedures

Fred S. Azar, Philips Medical Systems (United States)

Xavier Intes, Rensselaer Polytechnic Institute (United States)

2 Microscopy

Caroline Boudoux, Ecole Polytechnique de Montréal (Canada)

Yu Chen, University of Maryland, College Park (United States) 
3 Multimodal Tomography/Spectroscopy Imaging

Michael A. Mastanduno, Thayer School of Engineering at Dartmouth (United States)

Fred S. Azar, Philips Medical Systems (United States)

4 Agents, Reconstruction, and Analysis

Mark J. Niedre, Northeastern University (United States)

Xavier Intes, Rensselaer Polytechnic Institute (United States) 


\section{Introduction}

Data generated by novel imaging technologies such as optical tomography are complex to analyze due to the inherent scattering of light through anatomical systems. Cross validation and direct comparison with established methods in other imaging modalities are especially challenging. There is critical need for new computational techniques to provide rapid, accurate and cost-effective means for quantification and characterization of such data, either independently or integrated with other modalities. These computational methods will enable faster acceptance of novel imaging modalities into viable clinical and/or pre-clinical systems. The applications are diverse and range from imaging at the cellular level to the whole body while incorporating molecular, functional and anatomical information.

The conference objectives are to provide a forum:

- to review and share recent developments in novel multimodal imaging techniques,

- to report development of novel computational methods, and

- to bring together the optical imaging and image analysis communities.

Topics include, but are not limited to:

- multimodal imaging integrating structural, molecular and functional information

- 2D, 3D, 4D, tomographic and / or multi-spectral imaging

- imaging analysis and/or image processing techniques applied to optical imaging (e.g. visualization, segmentation, registration)

- detection and diagnostic analysis techniques which may provide better quantitative and/or diagnostic insight into clinical and pre-clinical imaging (e.g. methods for quantitative measurements, computer-assisted diagnosis)

- imaging analysis and/or image processing techniques used to combine optical imaging with other imaging modalities (e.g. MR, x-ray, PET)

- image analysis, computational methods and reconstruction approaches which may help bring optical imaging into the clinic (visual rendering of complex data set, novel algorithms for assisted optical reconstruction)

- clinical evaluation of these new technologies (Physiological and functional interpretation of image data, visual perception and observer performances, validation of quantitative assessment of optical signatures in-vivo).

Fred S. Azar Xavier Intes 
Proc. of SPIE Vol. $8937893701-10$

Downloaded From: https://www.spiedigitallibrary.org/conference-proceedings-of-spie on 26 Apr 2023 Terms of Use: https://www.spiedigitallibrary.org/terms-of-use 